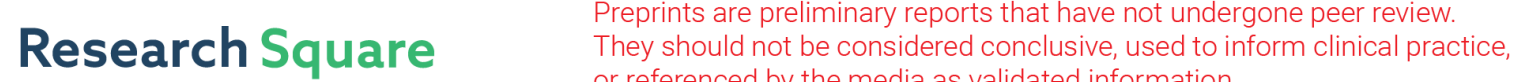 \\ or referenced by the media as validated information. \\ Chitin Matrix and Ultrastructure of Phosphate- Shelled Brachiopods
}

Oluwatoosin Agbaje ( $\nabla$ toosin.agbaje@mq.edu.au )

Macquarie University

Glenn Brock

Macquarie University

Zhifei Zhang

Northwest University

Yue Liang

Northwest University

Simon George

Macquarie University

Lars Holmer

Uppsala University

\section{Research Article}

Keywords: microRaman spectroscopy, chitin, fibrous proteins, biomineralization, spatial ultrastructure

Posted Date: December 17th, 2020

DOl: https://doi.org/10.21203/rs.3.rs-129606/v1

License: (c) (i) This work is licensed under a Creative Commons Attribution 4.0 International License.

Read Full License 


\title{
Chitin matrix and ultrastructure of phosphate-shelled brachiopods
}

\section{Oluwatoosin B. A. Agbaje, ${ }^{\text {a,b,c* Glenn A. Brock, }}{ }^{\text {,d }}$ Zhifei Zhang, ${ }^{\text {d }}$ Yue Liang, ${ }^{\text {d }}$ Simon C.} George, ${ }^{b}$ Lars E. Holmer ${ }^{a, d}$

${ }^{a}$ Department of Earth Sciences, Palaeobiology, Uppsala University, Uppsala, Uppsala, Sweden

${ }^{\mathrm{b}}$ Department of Earth and Environmental Sciences and MQ Marine Research Centre, Macquarie University, Sydney, Australia.

${ }^{\mathrm{c}}$ Department of Biological Sciences, Macquarie University, Sydney, Australia.

${ }^{\mathrm{d}}$ State Key Laboratory of Continental Dynamics, Shaanxi Key Laboratory of Early Life \& Environments, Department of Geology, Northwest University, Xi'an, 710069, China.

* Correspondence: toosin.agbaje@mq.edu.au; toosin91014@gmail.com

\begin{abstract}
Phosphate-shelled brachiopods differ in filter-feeding life style, with Lingula anatina an active
\end{abstract} infaunal burrower, and Discinisca tenuis a shallow marine epibenthic animal. The shells of these biomineralized organisms are built of organophosphatic constituents, the organic fibres/sheets reinforced with calcium phosphate (Ca-phosphate) to provide a sophisticated ultrastructural robustness. This investigation studied the nature of organic fibres in order to improve our understanding of how design principles are relevant to biominerals. Unlike the powdered samples that were commonly used in previous studies, for the first time organic fibres were isolated and the shell fractions were purified, in order to study the content and nature of the biopolymer fibres. Ultrastructural analysis, thermal gravimetric analysis and spectroscopic analyses reveal that the core polysaccharide framework is composed of layers of $\beta$-chitin sheets that are coated with a fibrous protein matrix. The chitin matrix in Lingula shells, 26.6 wt.\%, is about two-fold higher wt.\% compared to Discinisca shells, 12.9 wt.\%. After thermal gravimetric analysis, skeletal imaging of these shells shows important differences. Discinisca contains just a single layer that is $\sim 21.0 \mu \mathrm{m}$ thick. In contrast, Lingula exhibits two separate layers: the thicknesses of the primary- and secondary-layers are $\sim 20.3 \mu \mathrm{m}$ and $\sim 8.1$ 
$\mu \mathrm{m}$, respectively. Taken together, the data shows that the chitin matrix contributes to increased skeletal strength, making Lingula highly adapted for life as an active burrower. In comparison, Discinisca contains less chitin and lives as attached epibenthos in a shallow marine environment.

Keywords: microRaman spectroscopy; chitin; fibrous proteins; biomineralization; spatial ultrastructure

\section{Introduction}

Biominerals such as seashells, teeth or bones are produced by living organisms and formed into functional architectures under natural selection, typically as inorganic-organic nanocomposites. Inorganic matrices comprise calcium carbonates and phosphates, whereas organic macromolecules constitute a combination of soluble- and insoluble-organic components, primarily protein and polysaccharide layers which provide a scaffolding for the inorganic phase $\mathrm{e}^{1,2}$. Water insoluble macromolecules are most frequently built from monomers based either on sugars or peptides ${ }^{3,4}$. Sugar monomers and biomolecules based on peptides are present throughout the animal kingdom ${ }^{2}$. The former are chemically modified most commonly by amination, and are referred to as chitin or chitosan, depending largely on the degree of

47 subsequent deacetylation ${ }^{2,5}$. However, biomolecules based on peptides can either be functional or structural proteins comprised of a variety of fibrous, tubular and collagen triple helices ${ }^{3}$. In the matrix sheets of shell biominerals, the core polysaccharide framework is composed of the interlamellar structure of $\beta$-chitin, and is frequently reinforced and/or composited with extracellular matrix ${ }^{2}$, other biomolecules include glycosaminoglycans ${ }^{6,7}$ and/or inorganic matrices $^{8}$. These composite materials are high-strength yet lightweight, and provide functional flexibility, support ultrastructures, mechanical stability and compressive strength ${ }^{4,8,9}$. The composition of organic-inorganic matrices form extraordinary arrays of diverse biomineralized ultrastructures which eventually facilitate adaptation to a diverse suite of habitats ${ }^{10,11}$. 
Brachiopods are a diverse group of marine, sessile and benthic filter-feeding lophophorate animals that are categorised into three subphyla: Linguliformea, Craniiformea and Rhynchonelliformea $^{12}$. Craniiformea and Rhynchonelliformea utilize calcitic calcium carbonate and organic constituents, about $2 \%$, to hierarchically assemble ultrastructures of the shell ${ }^{13}$. In contrast, linguliform brachiopods such as Lingula and Discinisca use organic biopolymers reinforced with Ca-phosphate to produce the shell (e.g. $\left.{ }^{14}\right)$. The shell biominerals of Linguliformea consist of carbonate-substituted fluorapatite $\left(\mathrm{Ca}_{10}\left(\mathrm{PO}_{4}\right)_{6} \mathrm{~F}_{2}\right.$; francolite $)$ and originated some 530 million years ago in the early Cambrian as part of the emergence of biomineralization across disparate animal clades ${ }^{12,15}$. These biominerals exhibit distinctive features including ciliated lophophores, chitinous setae, as well as a tail-like pedicle for anchoring to (or within) the substrate ${ }^{12,16}$. Typical Discinisca uses a muscular pedicle for attachment to hard substrates, so as to survive wave action in the steeper slopes of the shallow seafloor ${ }^{10}$. In contrast, Lingula uses a pedicle to prop itself up with the shell against the sediment. The downward U-shaped burrowing is accomplished by cyclical complex motions of the valves against the sediment, with the pedicle trailing behind the shell ${ }^{10,11,16-18}$. Definitive evidence for an active U-shaped burrowing lingulid lifestyle is unknown from the Palaeozoic, where the obolids burrowed pedicle first ${ }^{16-18}$; the first appearance of the U-shaped burrows likely occurred during the Mesozoic; it may have been connected with the de-mineralization and more flexible shell that have been discussed here for the survival of Lingulidae, against the erosion of the substrate since the early Palaeozoic ${ }^{10,16-18}$.

Linguliform shells are used as paleoenvironmental proxies due to their enviably complete fossil record and their sporadic distribution in modern oceans ${ }^{12,19}$. Despite their palaeontological importance, the growth mechanism of brachiopod shells is not clearly understood, and regarding the key components of organic biopolymers, detailed structural and molecular analyses are of great interest. Although biochemical studies and spectroscopic analyses on 
powdered brachiopod samples have identified proteins associated with chitin from linguliform shells (e.g. ${ }^{6,20,21}$ ), the composite fibres have not been characterised, so little is known about the nature of the organic sheets. Chemical fixation and scanning electron microscopy (SEM) were used to propose that the organic fibrils in linguliform shells are composed of chitin, a dense mat of fibrils which are probably collagenous, and membranous laminae within the shell layers ${ }^{7,22}$. However, these previous studies were based on a more or less complete mixture of organic biopolymers and Ca-phosphate mineral. It is necessary to establish an easy and fast method to reveal the composition of the organic sheet layers in brachiopod shells. The approach of this study is to use field emission gun-SEM (FEG-SEM), and comparison of the imaged region with the natural composite biominerals analysed by microRaman spectroscopy and Fourier transform infrared (FTIR) spectroscopy. This study had two main goals: firstly to identify the major organic frameworks in lingulid shells, and secondly to determine the skeletal formation and components of the shell biominerals. This investigation is of interest for understanding the morphological structures of fossilised, recent and modern phosphate-shelled brachiopods and the biosynthesis of organic-inorganic composites, and for the design of skeletal structures of new materials. Also, this study provides direct evidence on skeletal biomineral evolutionary adaptions of active burrowing and epibenthic lingulids for their different habitats.

\section{Results}

\section{Vibrational spectroscopy - microRaman and FTIR spectra}

Raman spectra of organic fibres from the shell samples (Fig. 1) show absorption bands that are typical of chitin ( $N$-acetyl-D-glucosamine). The band assignments are listed in SI Table $\mathbf{1}$ and are compared with the spectrum of standard $\alpha$-chitin and the literature ${ }^{23-26}$. The spectra of the organic fibres reveal the presence of $\mathrm{C}=\mathrm{O}$ (carbonyl) functional groups based on the amide $\mathrm{I}$ stretching vibration at $\sim 1654 \mathrm{~cm}^{-1}$, and correspond primarily to the $\beta$-form of chitin. The 
deconvolutional fit of the amide I band in the $1580-1720 \mathrm{~cm}^{-1}$ range (SI Fig. 1) has some ubiquitous features with that of standard $\alpha$-chitin, but the vibrational bands have different area percentages (SI Table 2). The rocking $\mathrm{CH}_{2}$ vibrations at $1376 \mathrm{~cm}^{-1}$ and the amide III bands in the $1202-1327 \mathrm{~cm}^{-1}$ range are predominantly assigned to organic biopolymers (Fig. 1). The $\mathrm{CH}$ deformation of the $\beta$-glycosidic bond band at $897 \mathrm{~cm}^{-1}$ for $D$. tenuis and at $\sim 902 \mathrm{~cm}^{-1}$ for L. anatina is present at $895 \mathrm{~cm}^{-1}$ in standard $\alpha$-chitin. Bands at $1003 \mathrm{~cm}^{-1}$ in L. anatina and $1005 \mathrm{~cm}^{-1}$ in $D$. tenuis are not present in standard $\alpha$-chitin and are attributed to the aromatic C$\mathrm{C}$ stretch of fibrous insoluble protein ${ }^{27-29}$. The vibrational bands at $\sim 856 \mathrm{~cm}^{-1}$ and $\sim 820 \mathrm{~cm}^{-1}$ are assigned to a combination of C-C and C-O stretching, and appear in L. anatina only. Caphosphate vibrational bands at $964 \mathrm{~cm}^{-1}, 608 \mathrm{~cm}^{-1}$ and $581 \mathrm{~cm}^{-1}$ are only present in the D. tenuis spectrum (Fig. 1; SI Fig. 2). An attempt to completely remove inorganic components to expose the chitin framework in D. tenuis proved unsuccessful, because the organic macromolecules were completely removed during the extraction and purification stages, instead of the inorganic matrix. This was most likely due to the fact that both Ca-phosphate and the framework of organic biopolymers form complexes to produce shell ultrastructure.

FTIR spectroscopy was used to probe and/or identify the molecular and functional properties of the organic fibres from the shell samples, and used for comparison the $\alpha$-chitin standard (Fig. 2). The amide I of the insoluble matrix shows a broad band with a partial splitting pattern in two bands at $1646-1652 \mathrm{~cm}^{-1}$ and $1630-1635 \mathrm{~cm}^{-1}$, while standard $\alpha$-chitin has two bands at $1656 \mathrm{~cm}^{-1}$ and $1621 \mathrm{~cm}^{-1}$. The spectra at $1550 \mathrm{~cm}^{-1}$ (Amide II), in the range $1203-1308 \mathrm{~cm}^{-1}$ (Amide III), and the stretching $\mathrm{C}-\mathrm{O}$ bands in the $1153-950 \mathrm{~cm}^{-1}$ range (Fig. 1; SI Fig. 2) are indicative of chitin. The fingerprint region of the organic fibres of the phosphate-shelled brachiopods are doublet bands at 702-708 $\mathrm{cm}^{-1}$ and 691-692 $\mathrm{cm}^{-1}$, suggesting crystalline chitin. The stretching band of the $\mathrm{OH}$ group for shell samples is centred at $~ 3424 \mathrm{~cm}^{-1}$, with a shoulder near $3532 \mathrm{~cm}^{-1}$. Other spectra bands for amide A $\left(3282-3272 \mathrm{~cm}^{-1}\right)$, amide B $\left(3106-3095 \mathrm{~cm}^{-}\right.$ 
$130{ }^{1}$ ), and the $\mathrm{C}-\mathrm{H}$ stretching regions in the $2952-2851 \mathrm{~cm}^{-1}$ range are all characteristics of crystalline chitin and/or a protein motif ${ }^{9}$. The detail bands and functional groups are assigned in SI Table 1.

\section{Morphology of the organic fibre extracts}

134

135

136

137

Surface imaging of the organic fibres shows ultrastructural features of biopolymers, although the fibre morphology varies from shell to shell (Fig. 3). Organic fibres in L. anatina contain pores between the fibres (Fig. 3a), and closer imaging of the radiating units of the ridges reveals organic granules (Fig. 3a'). The organic fibre extract from $D$. tenuis shows native lamellar units (Fig. 3b). These are compare with the rheomorphic folding discussed by previous authors ${ }^{7}$, suggesting that in the present study the polymeric structure of the polysaccharide is preserved ${ }^{26}$. Organic nanofiber ultrastructure typical of chitin is observed in D. tenuis (Fig. 3b'), unlike the fibrous structure found in the organic fibre extract of L. anatina.

\section{Structural imaging of brachiopod shells after demineralization and deproteination}

In the shells of Lingula, there are apatite-rich lamellae and organophosphatic-rich lamellae (Figs. 4a, b). The thickness of the apatite-rich layers is up to $840 \mathrm{~nm}$, whereas the thickness of the organophosphatic-rich lamellae is up to $1.5 \mu \mathrm{m}$ (Fig. $\mathbf{4 a})$. In the organophosphatic lamellae, the organic sheet laminations are parallel to the Ca-phosphate sub-lamellae (Fig. $\mathbf{4 b}$ ), but do not permeate into the apatite-rich lamellae which are roughly perpendicular (Fig. $\mathbf{4 b}$ ). Within the apatite-rich laminae of Lingula, there are nanoscale fibrils that are mineralized with Caphosphate nanoparticles $(\sim 50-70 \mathrm{~nm})$ to form a fibrous biocomposite (Fig. 4c). FEG-SEM imaging of Lingula reveals composite organic sheets with Ca-phosphate granules (SI Fig. 3a).

These represent several layers that were peeled off the shells to form organic fibres for this study (see materials and methods). Some biomineralized nanofibrils are arranged approximately perpendicular to the micro-laminations (SI Fig. 3a). 
After demineralization and deproteination, the shell of Discinisca is permeated by canals with diameters of $\sim 90-120 \mathrm{~nm}$ (Fig. 4d). The conspicuous sets of canals consist of laminae with various aggregates of organic-coated granules in the 50-100 nm range (Fig. 4e; SI Fig. 3b). As shown in Fig. 4f, the shell of Discinisca is composed of $\sim 50-60 \mathrm{~nm}$ spherical Ca-phosphate nanoparticles, with the aggregates of protein-coated granules naturally compacted to form mosaics (see Fig. 4f), and compare with the previous study ${ }^{7}$. Rod-shaped crystallites (Fig. 4f) may perhaps be self-organized chitin fibrils, which are coated with proteins before mineralization. The apatitic components entwine with the chitin-protein fibrils (Fig. 4e), resulting in a stratiform succession of microscale laminae ${ }^{22,30}$.

\section{Thermal gravimetric analysis and differential thermal gravimetric analysis}

TGA and DTG analysis of brachiopod shell samples and standard $\alpha$-chitin was carried out to detect degradation features in the organic matrix. TGA weight losses and multistage decompositional steps occur for the brachiopod shells and $\alpha$-chitin (Fig. 5). The first weight loss of $5.1 \mathrm{wt} \%$ to $5.6 \mathrm{wt} \%$ for both L. anatina and D. tenuis occurs over the $30-200^{\circ} \mathrm{C}$ range, and is attributed to removal of water. The second weight loss of $26.6 \mathrm{wt} \%$ for L. anatina and 12.9 wt\% for D. tenuis (Fig. 5a) is recorded in the $200-650^{\circ} \mathrm{C}$ range and is due to the combustion of a complex mixture of shell macromolecules, including chitin fibre and a protein moiety ${ }^{25,31}$, that is occluded in the apatitic shell biominerals. The maximum DTG value for the commercially-used $\alpha$-chitin is recorded at $357^{\circ} \mathrm{C}$, whereas the peak shift occurs at $335^{\circ} \mathrm{C}$ for L. anatina and $347^{\circ} \mathrm{C}$ for D. tenuis (Fig. 5b). The values for the shell biominerals are in the $250-350^{\circ} \mathrm{C}$ range for thermal stability of $\beta$-chitin ${ }^{25,31}$. Lower temperature peaks are considered a measure of lower thermal stability ${ }^{31}$. However, the DTG thermogram of L. anatina is similar to $\alpha$-chitin, and shows a broad peak at around $600^{\circ} \mathrm{C}(\mathbf{F i g} . \mathbf{5 b})$, which is attributed to the thermal degradation of a pyranose ring and the decomposition of residual carbon ${ }^{31}$. DTG thermograms of shell biominerals reveal apatitic peaks at $840^{\circ} \mathrm{C}$ for $L$. anatina and $740^{\circ} \mathrm{C}$ for D. tenuis. The 
residual mass after heating to $900^{\circ} \mathrm{C}$ is $65.9 \mathrm{wt} \%$ for L. anatina and $79.6 \mathrm{wt} \%$ for D. tenuis.

This suggests the presence of inorganic matrices that were not extracted during the acidtreatment stage.

\section{Ultrastructural imaging of brachiopod shells}

The organophosphatic-shelled brachiopods were heated to remove organic layers and granules in order to reveal the skeletal ultrastructure using FEG-SEM (Figs. 6 and 7). After complete demineralization, deproteinization and thermal analyses, the brachiopod shells maintained structural integrity. Back-scattered electron imaging of the external shell surface of Lingula shell reveals a very similar ultrastructure to the original shell prior to thermal treatment (see SI Fig. 4), with many features retained such as pores (canals) and Ca-phosphate rod-shaped lathes (Fig. 6a). The diameters of the pores are between 123.6-152.1 nm long and 230.3-371.4 nm wide. The shells of Lingula have two layers: the primary layer is $\sim 20 \mu \mathrm{m}$ thick, while the secondary layer is $\sim 8 \mu \mathrm{m}$ thick (Fig. 6b). Higher magnification of the shell cross-section displays the morphology of the primary layer (Fig. 6c), which is different from the secondary layer that is made of thin, overlapping tablets (Fig. 6d). Each tablet in Lingula shells is rhomboidal, with lengths up to $12.2 \mu \mathrm{m}$ and widths up to $6.6 \mu \mathrm{m}$. In contrast, the primary layer is organised into overlapping rod-shaped lathes that are several $\mathrm{nm}$ long and are of different shapes, but are not deformed despite thermal gravimetric analysis.

The shell of D. tenuis is composed of a single layer that is $21 \mu \mathrm{m}$ thick (Fig. 7a). Higher FEGSEM magnification of the shell cross-section shows that rod-shaped lathes are arranged in alternating orientations. The rod-shaped lathes are several hundred nm long (Fig. 7b). The external surface of D. tenuis is composed of rod-shaped lathes that are randomly oriented and of variable size and shape, with most lengths up to $3.8 \mu \mathrm{m}$ and widths up to $375 \mathrm{~nm}$ (Fig. 7c). The large columnar crystal in Fig 7c is $7.2 \mu \mathrm{m}$ long and $1.3 \mu \mathrm{m}$ wide. FEG-SEM imaging 
reveals spherical imprint tablets (Fig. 7d), with the inner component composed of rod-shaped lathes (Fig. 7e). Interestingly, this observation contrasts to previous work which showed the inner layer of a uni-lamellar tablet of $D$. tenuis was composed of small granules ${ }^{32}$. This disparity could be attributed to the different growth stages of brachiopod shells: the present study analysed a mature shell of Discinisca, while Williams et al. (2001) analysed juvenile shells. In the shell's studied here, the diagonal length of the largest tablets is $19.7 \mu \mathrm{m}$, while most tablets are $\sim 16 \mu \mathrm{m}$ long and $\sim 15 \mu \mathrm{m}$ wide (Fig. 7d).

MicroRaman and energy dispersive X-ray spectroscopy of skeletal apatitic shells after

\section{heating}

After thermal analysis of L. anatina and D. tenuis, Raman spectra amide bands and other organic bands that were originally present (Fig. 1) are no longer visible (Fig. 8a). Instead, the Raman spectra reveal the internal vibrational modes of phosphate groups (Fig. 8b). The strong absorption band at $964 \mathrm{~cm}^{-1}$ is assigned to $v_{1} \mathrm{PO}_{4}{ }^{3-}$ and is due to the non-degenerated symmetric stretching of the P-O band. Bending modes of two $v_{2} \mathrm{PO}_{4}{ }^{3-}$ vibrational bands appear at $430 \mathrm{~cm}^{-}$

$217{ }^{1}$ and $\sim 450 \mathrm{~cm}^{-1}$. The bands present in the $1035-1080 \mathrm{~cm}^{-1}$ range are assigned to the triply degenerated asymmetric stretching mode of $v_{3} \mathrm{PO}_{4}{ }^{3-}$. It is speculated that the specific bands at 1042, 1053 and $1080 \mathrm{~cm}^{-1}$ correspond to typical fluorapatite ${ }^{33,34}$. The vibrational mode at $\sim 1022 \mathrm{~cm}^{-1}$ is a characteristic of apatite containing divalent ions and vacancies on the crystals instead of monovalent ions ${ }^{35,36}$. In the region of the $v_{4} \mathrm{PO}_{4}{ }^{3-}$ bending mode, four distinguishable bands appear at 581, 591, 607 and $617 \mathrm{~cm}^{-1}$. The $997 \mathrm{~cm}^{-1}$ and $1010 \mathrm{~cm}^{-1}$ bands correspond to the P-O stretching vibration of monohydrogen phosphate $\left(\mathrm{HPO}_{4}{ }^{2-}\right) . \mathrm{A} 1010 \mathrm{~cm}^{-1}$ band occurs in the octacalcium phosphate phase ${ }^{36,37}$, whereas a $997 \mathrm{~cm}^{-1}$ band occurs in an apatitic environment ${ }^{34,38}$. The D. tenuis spectrum reveals a small $648 \mathrm{~cm}^{-1}$ band that corresponds to a liberational mode of the hydroxyl groups and/or the $v_{4}$ in-plane deformation bending mode of

$227 \mathrm{CO}_{3}{ }^{2-33,36}$. The small band at $870 \mathrm{~cm}^{-1}$ arises from the bending mode $\left(v_{2}\right)$ of the $\mathrm{CO}_{3}{ }^{2-}$ group ${ }^{36}$ 
and/or $\mathrm{HPO}_{4}{ }^{2-}$ ions ${ }^{39}$. The bands at $795 \mathrm{~cm}^{-1}$ and $828 \mathrm{~cm}^{-1}$ in the L. anatina spectrum correspond to $v_{4}$ deformation bending modes of $\mathrm{CO}_{3}{ }^{2-33}$.

230 Energy dispersive X-ray measurements after thermal gravimetric analysis reveal that calcium, 231 phosphorus, oxygen, carbon and fluorine are the dominant elements in both samples, with minor magnesium (SI Fig. 5). In addition, minor sodium and sulphur were identified in $D$. tenuis shell. The sulphur signal is assigned predominantly to left-over sulphated glycosaminoglycans. The calcium-phosphorus atomic ratio in L. anatina ranges from 1.69:1 (primary layer) to $1.71: 1$ (secondary layer), similar to the ratio of $D$. tenuis $(1.66: 1)$. The calcium-phosphorus atomic ratios in this study are similar to the expected ratio of $1.67: 1$ for hydroxyapatite, $\mathrm{Ca}_{10}\left(\mathrm{PO}_{4}\right)_{6}(\mathrm{OH})_{2}$.

\section{Discussion}

The presented data provide a much better characterisation of the core organic fibres in two extant organophosphatic brachiopod shells that have a long fossil record, compared to previous studies ${ }^{6}$. The core fibres are structure-forming and stabilizing polysaccharides, composed of chitin. After purification, the thermal degradation results confirm the presence of a chitin matrix in the shells of two representative taxa belonging to separate superfamilies of lingulid organophosphatic brachiopods, L. anatina (Linguloidea) and D. tenuis (Discinoidea). The $L$. anatina shells are composed of two-fold more abundant chitin matrix compared to the D. tenuis shells. Chitin is rarely found in a pure state in nature, and is most commonly linked covalently with proteins ${ }^{40}$. Pure chitin can be difficult to isolate, for example in mollusc shell biominerals ${ }^{1,41}$ and brachiopod shells ${ }^{6}$. Nevertheless, chitin can be readily distinguished using vibrational spectroscopy, such as by Raman and FTIR spectroscopy, due to their distinctive bands ${ }^{23-25}$. The analyses presented here using vibrational spectroscopy reveal chitin fibres entwined with minor shell proteins, supporting previous work ${ }^{6}$. 
252 The spectral bands of the organic fibres compare closely with the chitinous system containing

253

254

255

256

257

258

259

260

261

262

263

264

265

266

267

268

269

270

271

272

273

274

275

276 amino-polysaccharide chitin (Figs. 1 and 2). The FTIR and Raman spectra bands associated with the amide I vibrational modes reveal broad and complex bands that are centred at high frequencies and are attributed to $\beta$-chitin. The Raman band is centred at $\sim 1655 \mathrm{~cm}^{-1}$ for brachiopod shells, and is commonly assigned to stretching of the $\mathrm{C}=\mathrm{O}$ group hydrogen bonded to $\mathrm{N}-\mathrm{H}$ group of the neighbouring intra-sheet chain ${ }^{24}$. In the FTIR spectra, the amide I position is at $1652 \mathrm{~cm}^{-1}$ for $D$. tenuis. The band shifts by $\sim 19 \pm 3 \mathrm{~cm}^{-1}$ towards a lower frequency for $L$. anatina (SI Table 1). The FTIR spectra $1634 \mathrm{~cm}^{-1}$ band for D. tenuis and a $1646 \mathrm{~cm}^{-1}$ band for L. anatina are present as a shoulder, and are likely due to defects in the crystalline structure of the chitin fibre, or possibly a shell-associated protein. The deconvolutional fit of the amide I band for FTIR spectra in the $1580-1720 \mathrm{~cm}^{-1}$ range also reveals the band at $\sim 1622 \mathrm{~cm}^{-1}$, compare with the $\alpha$-chitin band at $1620 \mathrm{~cm}^{-1}$ (SI Fig. 6). The occurrence of this band may show a specific hydrogen bond of carbonyl $(\mathrm{C}=\mathrm{O})$ with the hydroxymethyl group of the next chitin residue of the same chain or due to the presence of enol form of the amide moiety ${ }^{42,43}$. A $~ 1003$ $\mathrm{cm}^{-1}$ phenyl ring vibration is visible in the Raman spectra of the studzied brachiopod shells, and is commonly observed in the published spectra of collagen ${ }^{27,28}$. Recent analyses provide comprehensive data on D. tenuis and L. anatina shells, with identification of a collagen matrix as the primary protein motif within the inorganic matrix of phosphate-shelled brachiopods ${ }^{29}$.

After demineralization and deproteination, TGA reveals phosphatic soluble macromolecules of 14.0 wt.\% for L. anatina and 11.7 wt.\% for D. tenuis. Based on the previous work of Lévêque et al. ${ }^{44}$, there may be soluble shell proteins in Ca-phosphate shell biominerals that greatly contribute to the formation of crystalline apatite. The inorganic matrix provides the structural strength, stiffness and rigidity for many invertebrate shell biominerals, including organophosphatic brachiopod shells ${ }^{45}$. However, polysaccharide chitin offers increased strength and flexibility ${ }^{45,46}$. 
L. anatina is clearly laminated with an alternating chitinous system and biomineralized chitinphosphate layers. In contrast, lamination of the mineralization framework is less pronounced in the sessile epibenthic $D$. tenuis ${ }^{45,46}$. These authors concluded that biomineralized laminae provide strength to the shells of $L$. anatina, and allow bending flexibility, a factor that may have been important in the more complex shell-first burrowing of living lingulids. However, flexibility is less important for the shallow marine epibenthic phosphate-shelled brachiopods 45. The analyses reported here reveal the spatial ultrastructure, apatitic and polysaccharide matrix of two important phosphate-shelled brachiopods, and demonstrate an effective bioanalytical approach for analysis of lophotrochozoan shell biominerals.

The FEG-SEM imaging, after thermal analyses, reveals pores and spaces that were probably originally occupied by organic macromolecules and/or amorphous Ca-phosphate particles in the phosphate-shelled brachiopods (Figs. 6; 7). Cross-sections of L. anatina shells show rodshaped lathes that are continuous, and rhomboidal tablets (Fig. 6). In contrast, cross-sections of D. tenuis reveal small domains of rod-shaped crystals within a confined Ca-phosphate mineral phase (Fig. 7a and b). In the absence of crystals, it seems that Ca-phosphate confinement restricts the growth of the apatitic crystallites, consistent with the formation of bone-like crystalline apatite ${ }^{47}$. Although the external shell surface of D. tenuis confirmed several rod-shaped crystals that are randomly orientated, these are not comparable to the crystal lathes that form the external surface of L. anatina.

The SEM imaging of D. tenuis after thermal analysis reveals apatitic tablets, confirming the previous work of Williams et al ${ }^{32}$. These authors also revealed a siliceous mosaic in the metamorphosis larval shell of $D$. tenuis, whereas this study shows almost no silicon peak in the EDX analysis of D. tenuis (SI Fig. 5). However, EDX after thermal analysis reveals a sulphur band which is incorporated into apatitic aggregates. Williams et al ${ }^{32}$ suggested that the matrix of the tablets is mainly a soluble polymer, presumably sulphated glycosaminoglycans. 
1. Based on field emission gun scanning electron microscopy and vibrational spectroscopic analyses, phosphate-shelled brachiopods (Lingula anatina and Discinisca tenuis) contain chitin fibre composites with a fibrous protein concentration, which create suitable microenvironments for inorganic nanoparticle aggregation.

2. The polysaccharide-apatitic matrix composition of the shells of L. anatina is distinctly different from that of $D$. tenuis. For L. anatina, polysaccharide fibre component is internally reinforced by nanoscale Ca-phosphate matrix and distinctively laminated. A different shell design apparently favours $D$. tenuis in that it contains a continuous compact layer with canals and does not contain non-mineralized laminae.

3. It is proposed that the high content of the polysaccharide chitin matrix of L. anatina may contribute to its complex burrowing mechanism, in which the valves function as flexible digging tools combined with the injection of water in the shell-first burrowing, thus producing $\mathrm{U}$-shaped burrows. The chitin matrix of $L$. anatina is composed of brittle sheets or lamellae, forming a laminar shell design that produces a flexible shell. A flexible shell gives an advantage for burrowing and prompt movements in the burrow $10,11,16-18$.

4. This study highlights the differences in the skeletal ultrastructures of L. anatina and D. tenuis. L. anatina has a distinctive two-layer structure, while D. tenuis has a single layer with an imprint of a Ca-phosphate mineral. However, based on TGA, the amount of soluble shell macromolecules is similar, $14.0 \mathrm{wt} . \%$ for $L$. anatina and $11.7 \mathrm{wt} . \%$ for $D$. tenuis.

\section{Materials}


326 Three phosphatic brachiopod shells belonging to Lingula anatina Lamarck, 1801 and

327 Discinisca tenuis Sowerby, 1847 (SI Fig. 7) were used for this study, including both recently

328 alive and live specimens (modern). Recently alive shells of D. tenuis and L. anatina were 329 collected from Walvis Bay, Namibia, and from Moreton Bay, Queensland, Australia, 330 respectively. The live specimens of L. anatina that were used in this study were collected in the Bay of Guangxi, China, and were preserved in $10 \%$ formalin. While long exposure of biological samples to formalin does not alter the organic composition, it does diminish the fracture toughness due to etching/removal of calcium phosphate. Shells of brachiopods are laminated and are covered with a non-mineralized organic layer, the periostracum, which ranges from $1-30 \mu \mathrm{m}$ thick ${ }^{30,48}$.

\section{Sample preparation and thermal gravimetric analysis}

The three shell samples were mechanically cleaned with a scalpel, and then washed with MilliQ water to remove organic and inorganic contaminants. Samples were soaked in hydrogen peroxide (35\%; Chem-Supply, UN2014) for about 2 hours to remove surface organic detritus. Each shell sample was demineralized with $5 \%$ acetic acid at room temperature for about $48 \mathrm{~h}$. Subsequently, shell samples were washed several times with Milli-Q water, followed by deproteinisation and/or depigmentation with $5 \% \mathrm{NaOH}$ at room temperature for $40 \mathrm{~h}$. Several layers were peeled off the shells using a tweezer after $24 \mathrm{~h}$ in $\mathrm{NaOH}$, and are termed the organic fibres. The remaining shell samples and the organic fibres were collected from the solution, washed in Milli-Q water until a pH of about 6.8 was reached, and then rinsed in cold acetone twice. The shell samples and organic fibres were then dried at room temperature.

Shell samples was broken into a few mm-sized pieces and was heated using a thermal gravimetric analyzer (TGA) model 2050 (TA Instruments, USA) equipped with a differential thermal gravimetric (DTG) analyzer. About $10 \mathrm{mg}$ of sample was measured at a rate of 
$10^{\circ} \mathrm{C} / \mathrm{min}$ over a temperature interval from $25^{\circ} \mathrm{C}$ to $900^{\circ} \mathrm{C}$. The moisture content, organic

351

352

353

354

355

356

357

358

359

360

361

362

363

364

365

366

367

368

369

370

371

372

biopolymer content, and residual ash content were determined from mass losses. The analyses were recorded twice for each sample. $\alpha$-chitin extracted from shrimps (Sigma-Aldrich) was used as a standard for this study.

\section{MicroRaman and Fourier transform infrared Spectroscopy}

Raman spectra were recorded at room temperature using a Horiba Jobin Yvon LabRAM HR Evolution spectrometer equipped with an Olympus BX41 microscope and an automated $\mathrm{x}-\mathrm{y}$ stage. A red wavelength helium-neon laser $(633 \mathrm{~nm})$ was used and scattered light was dispersed by a grating with 600 grooves/mm (750 $\mathrm{nm}$ spacing). Rayleigh radiation was blocked using an edge filter. Spectra of the organic fibres were recorded in the $400-1800 \mathrm{~cm}^{-1}$ range with an acquisition time of $60 \mathrm{~s}, 10$ accumulations, and a delay time of $3 \mathrm{~s}$. In contrast, spectra of the minerals after TGA analyses were acquired with an acquisition time of $2-5 \mathrm{~s}, 20$ accumulations, and time was not delayed. For each sample, 3-4 spots were measured for spectral clarity. Data acquisition and spectra treatment were carried out with the commercially available program LabSpec v6 (HORIBA Jobin Yvon GmbH).

FTIR measurements were conducted as described previously ${ }^{1}$, with 64 accumulations and a resolution of $2 \mathrm{~cm}^{-1}$. Background spectra were measured at the start of each analysis. Spectra treatments were performed using the software Origin LabPro 2017. A linear baseline was subtracted for the spectra and for the amide I region, over the range of $1580-1720 \mathrm{~cm}^{-1}$. Peak fitting of the spectra was performed to reveal the different components of a spectrum based on Gaussian functions.

Field emission gun scanning electron microscope imaging and energy dispersive $X$-ray analysis 

detector SEM at an electron energy of $15 \mathrm{kV}$ and $7 \mathrm{~mm}$ walking distance. Data were processed using the Pro Suite software package.

\section{References}

1. Agbaje, O. B. A., Shir, I. B., Zax, D. B., Schmidt, A. \& Jacob, D. E. Biomacromolecules within

2. Ehrlich, H. Chitin and collagen as universal and alternative templates in biomineralization. Int. Geol. Rev. 52, 661-699 (2010).

3. Neville, A. C. Biology of fibrous composites: development beyond the cell membrane. (Cambridge University Press, 1993).

4. Naleway, S. E., Porter, M. M., McKittrick, J. \& Meyers, M. A. Structural design elements in biological materials: application to bioinspiration. Adv. Mater. 27, 5455-5476 (2015).

5. Weiss, I. M., Renner, C., Strigl, M. G. \& Fritz, M. A simple and reliable method for the determination and localization of chitin in abalone nacre. Chem. Mater. 14, 3252-3259 (2002).

6. Neary, M. T. et al. Contrasts between organic participation in apatite biomineralization in brachiopod shell and vertebrate bone identified by nuclear magnetic resonance spectroscopy. J. R. Soc., Interface 8, 282-288 (2011).

7. Williams, A., Cusack, M. \& Buckman, J. O. Chemico-structural phylogeny of the discinoid brachiopod shell. Philos. Trans. R. Soc., B. 353, 2005-2038 (1998).

8. Meyers, M. A., Chen, P.-Y., Lin, A. Y.-M. \& Seki, Y. Biological materials: structure and mechanical properties. Prog. Mater. Sci. 53, 1-206 (2008).

9. Rahman, M. A. \& Halfar, J. First evidence of chitin in calcified coralline algae: new insights into the calcification process of Clathromorphum compactum. Sci. Rep. 4, 6162 (2014).

10. Emig, C. C. Ecology of inarticulated brachiopods. Treatise on invertebrate paleontology, part H, brachiopoda (revised) 1, 473-495 (1997).

11. Thayer, C. W. \& Steele-Petrovic, H. M. Burrowing of the lingulid brachiopod Glottidia pyramidata: its ecologic and paleoecologic significance. Lethaia 8, 209-221 (1975).

12. Harper, D. A., Popov, L. E. \& Holmer, L. E. Brachiopods: origin and early history. Palaeontology 60, 609-631 (2017).

13. Williams, A. Treatise on invertebrate paleontology: Part H. Brachiopoda. Linguliformea, Craniiformea, and Rhynchonelliformea (part). Vol. 3 (Geological society of America, 2000).

14. Williams, A. et al. Treatise on Invertebrate Palaeontology (Part H, Brachiopoda Revised). Volume 6: Supplement (Boulder, CO, 2007).

15. Veizer, J. et al. ${ }^{87} \mathrm{Sr} /{ }^{86} \mathrm{Sr}, \delta^{13} \mathrm{C}$ and $\delta^{18} \mathrm{O}$ evolution of Phanerozoic seawater. Chem. Geol. 161, 59-88 (1999).

16. Zhang, Z., Shu, D., Han, J. \& Liu, J. Morpho-anatomical differences of the Early Cambrian Chengjiang and Recent lingulids and their implications. Acta Zool. 86, 277-288 (2005).

17. Savazzi, E. Burrowing in the inarticulate brachiopod Lingula anatina. Palaeogeogr. Palaeoclimatol. Palaeoecol. 85, 101-106 (1991). 
18. Savazzi, E. Burrowing sculptures and life habits in Paleozoic lingulacean brachiopods. Paleobiology 46-63 (1986).

19. Murdock, D. J. The 'biomineralization toolkit'and the origin of animal skeletons. Biol. Rev. (2020).

20. Iwata, K. Ultrastructure and mineralization of the shell of Lingula unguis Linne,(Inarticualte Brachiopod). Geol. Mineral. J. 20, 35-65 (1981).

21. Jope, M. The protein of brachiopod shell-VI. C-terminal end groups and sodium dodecylsulphate-polyacrylamide gel electrophoresis: Molecular constitution and structure of the protein. Comp. Biochem. Physiol., Part B: Biochem. Mol. Biol. 63, 163-173 (1979).

22. Williams, A., Cusack, M. \& Mackay, S. Collagenous chitinophosphatic shell of the brachiopod Lingula. Philos. Trans. R. Soc., B. 346, 223-266 (1994).

23. Ehrlich, H. et al. First evidence of chitin as a component of the skeletal fibers of marine sponges. Part I. Verongidae (Demospongia: Porifera). Journal of Experimental Zoology Part B: Molecular and Developmental Evolution 308, 347-356 (2007).

24. Focher, B., Naggi, A., Torri, G., Cosani, A. \& Terbojevich, M. Structural differences between chitin polymorphs and their precipitates from solutions-evidence from CP-MAS 13C-NMR, FT-IR and FT-Raman spectroscopy. Carbohydr. Polym. 17, 97-102 (1992).

25. Kaya, M. et al. On chemistry of $\gamma$-chitin. Carbohydr. Polym. 176, 177-186 (2017).

26. Lavall, R. L., Assis, O. B. \& Campana-Filho, S. P. $\beta$-Chitin from the pens of Loligo sp.: Extraction and characterization. Bioresour. Technol. 98, 2465-2472 (2007).

27. Morris, M. D. \& Mandair, G. S. Raman assessment of bone quality. Clin. Orthop. Relat. Res. 469, 2160-2169 (2011).

28. Wopenka, B., Kent, A., Pasteris, J. D., Yoon, Y. \& Thomopoulos, S. The tendon-to-bone transition of the rotator cuff: a preliminary Raman spectroscopic study documenting the gradual mineralization across the insertion in rat tissue samples. Appl. Spectrosc. 62, 12851294 (2008).

29. Agbaje, O. B., George, S. C., Zhang, Z., Brock, G. A. \& Holmer, L. E. Characterization of organophosphatic brachiopod shells: spectroscopic assessment of collagen matrix and biomineral components. RSC Adv. 10, 38456-38467 (2020).

30. Williams, A. \& Cusack, M. Evolution of a rhythmic lamination in the organophosphatic shells of brachiopods. J. Struct. Biol. 126, 227-240 (1999).

31. Hassainia, A., Satha, H. \& Boufi, S. Chitin from Agaricus bisporus: Extraction and characterization. Int. J. Biol. Macromol. 117, 1334-1342 (2018).

32. Williams, A., Lüter, C. \& Cusack, M. The nature of siliceous mosaics forming the first shell of the brachiopod Discinisca. J. Struct. Biol. 134, 25-34 (2001).

33. Antonakos, A., Liarokapis, E. \& Leventouri, T. Micro-Raman and FTIR studies of synthetic and natural apatites. Biomaterials 28, 3043-3054 (2007).

34. Litasov, K. D. \& Podgornykh, N. M. Raman spectroscopy of various phosphate minerals and occurrence of tuite in the Elga IIE iron meteorite. J. Raman Spectrosc. 48, 1518-1527 (2017).

35. Penel, G., Leroy, G., Rey, C. \& Bres, E. MicroRaman spectral study of the PO 4 and CO 3 vibrational modes in synthetic and biological apatites. Calcif. Tissue Int. 63, 475-481 (1998).

36. Koutsopoulos, S. Synthesis and characterization of hydroxyapatite crystals: a review study on the analytical methods. J. Biomed. Mater. Res., Part A. 62, 600-612 (2002).

37. Crane, N. J., Popescu, V., Morris, M. D., Steenhuis, P. \& Ignelzi Jr, M. A. Raman spectroscopic evidence for octacalcium phosphate and other transient mineral species deposited during intramembranous mineralization. Bone 39, 434-442 (2006).

38. Rey, C., Shimizu, M., Collins, B. \& Glimcher, M. Resolution-enhanced fourier transform infrared spectroscopy study of the environment of phosphate ions in the early deposits of a solid phase of calcium phosphate in bone and enamel and their evolution with age. 2: Investigations in the $v_{3} \mathrm{PO}_{4}$ domain. Calcif. Tissue Int. 49, 383-388 (1991). 
39. Ciobanu, C. S. et al. Synthesis, structure, and luminescent properties of europium-doped hydroxyapatite nanocrystalline powders. Journal of Nanomaterials 2012 (2012).

40. Kurita, K. Chitin and chitosan: functional biopolymers from marine crustaceans. Marine Biotechnol. 8, 203 (2006).

41. Osuna-Mascaró, A. J., Cruz-Bustos, T., Marin, F. \& Checa, A. G. Ultrastructure of the interlamellar membranes of the nacre of the bivalve Pteria hirundo, determined by immunolabelling. PloS one 10 (2015).

42. Kumirska, J. et al. Application of spectroscopic methods for structural analysis of chitin and chitosan. Marine Drugs 8, 1567-1636 (2010).

43. Rinaudo, M. Chitin and chitosan: properties and applications. Prog. Polym. Sci. 31, 603-632 (2006).

44. Lévêque, I., Cusack, M., Davis, S. A. \& Mann, S. Promotion of Fluorapatite Crystallization by Soluble-Matrix Proteins from Lingula Anatina Shells. Angew. Chem. Int. Ed. 43, 885-888 (2004).

45. Merkel, C. et al. Mechanical properties of modern calcite-(Mergerlia truncata) and phosphateshelled brachiopods (Discradisca stella and Lingula anatina) determined by nanoindentation. J. Struct. Biol. 168, 396-408 (2009).

46. Schmahl, W. W. et al. Hierarchical fibre composite structure and micromechanical properties of phosphatic and calcitic brachiopod shell biomaterials-an overview 72(2), 541-562 (2008).

47. Lotsari, A., Rajasekharan, A. K., Halvarsson, M. \& Andersson, M. Transformation of amorphous calcium phosphate to bone-like apatite. Nat. Commun. 9, 1-11 (2018).

48. Merkel, C. et al. Micromechanical properties and structural characterization of modern inarticulated brachiopod shells. J. Geophys. Res.: Biogeosci. 112 G02008 (2007).

\section{Acknowledgements}

OBAA is grateful to Uppsala University for support through the VR Project number 201803390. The research for this paper was supported by the Swedish Research Council (VR Project no. 2018-03390 to LEH, GAB and SCG), by the National Natural Science Foundation of China (41720104002, 41621003 and 41890844 to NWU members) and by a Zhongjian Yang Scholarship to LEH from the Department of Geology, Northwest University, Xi'an. GAB's research is also funded by a 1000 Talent Shaanxi Province Fellowship at Northwest University, Xi’an.

\section{Author contributions}

OBAA designed the study, carried out the analyses, interpreted the data and prepare the original manuscript. LY and ZZ provided live specimens of Lingula anatina; LEH provided recently alive Discinisca tenuis shells and GAB gave recently alive Lingula anatina shells. LEH, GAB 
and SCG coordinated the study. All authors reviewed the manuscript and gave final approval for publication.

\section{Additional Information}

Supplementary information accompanies this paper at https://doi.org/

\section{Competing interests}

The authors declare no competing interests.

Fig. 1 Raman spectra (acquired using a 633-nm laser) of chitin fibre from brachiopod shells: Lingula anatina (modern/living (ML) and Recent (RL), Recent Discinisca tenuis (DT), and pure $\alpha$-chitin $(\mathrm{Ch})$ as a reference. The baselines of the spectra are corrected. The amide I single band at $\sim 1654 \mathrm{~cm}^{-1}$ is due to chitin fibre, and is characteristic of $\beta$-chitin. This is dissimilar from $\alpha$-chitin that possesses double bands at 1617 and $1654 \mathrm{~cm}^{-1}$. The amide I band of Discinisca is broad compared to the Lingula shells. See SI Fig. 1 for band deconvolution. Discinisca also contains prominent phosphate $\left(v \mathrm{PO}_{4}{ }^{3-}\right)$ vibrational modes at $964 \mathrm{~cm}^{-1}, 608 \mathrm{~cm}^{-}$ ${ }^{1}$ and $581 \mathrm{~cm}^{-1}$. See SI Table 1 for band assignments.

Fig. 2 FTIR spectra of chitin fibre from brachiopod shells: Lingula anatina, Recent (RL) and modern/living (ML), Recent Discinisca tenuis (DT), and pure $\alpha$-chitin (Ch) as a reference. (a) Shows a larger wavenumber range $\left(4000-600 \mathrm{~cm}^{-1}\right)$ than the expanded range $\left(1800-600 \mathrm{~cm}^{-1}\right)$ in (b).

Fig. 3 Field emission gun scanning electron microscope images of $\beta$-chitin organic fibre from brachiopod shells. (a) Representative fibre surface of Lingula anatina showing pores and radiating units of the ridges. (a') The ridge is expanded to show nanoparticle granules. (b, b') External surface of Discinisca tenuis organic fibre showing a lamellar ultrastructure.

Fig. 4 Field emission gun scanning electron microscope images of sodium hydroxide-treated Lingula anatina (a-c) and Discinisca tenuis (d-f) shells. (a) Fracture surface of Lingula shell showing apatite-rich (Ap-rich) and organophosphatic-rich (OrgPhos-rich) laminae. (b) Organic sheets/fibres (blue arrows) in the organophosphatic-rich layer are highlighted. These sheets are arranged roughly perpendicular to the apatite-rich layer, but do not permeate into it. (c) Biomineralized ruptured fibrils (green arrows) on the fracture surface of an apatite-rich layer. The nanoparticle granule sizes are in the $\sim 50-70 \mathrm{~nm}$ range. (d) Ultrastructure of Discinisca shell depicting canals. (e) Nanoparticle granules in the $\sim 50-100 \mathrm{~nm}$ range, and organic fibrils 
534 (white arrows). (f) Fracture section showing nano-rods (dashed arrows), mosaics (mc), and 535 spherical micro-apatite in the 50-60 $\mathrm{nm}$ range (arrowheads).

537 Fig. 5 (a) Thermal gravimetric analysis data and (b) differential thermal gravimetric analysis 538 data of shell biominerals (LA: Lingula anatina, DT: Discinisca tenuis) and pure $\alpha$-chitin (Ch). 539 The bar chart in (a) represents the calculated total polysaccharide chitin contents in the 200$540650^{\circ} \mathrm{C}$ range. L. anatina and D. tenuis comprise $26.6 \mathrm{wt} . \%$ and $12.9 \mathrm{wt} . \%$ total polysaccharide 541 matrix, respectively.

542

Fig. 6 Lingula anatina shell architecture after thermal analysis by back-scattered electron imaging (a) and field emission gun scanning electron microscopy (b-d). (a) Representative external shell surface showing nano-sized crystal rods and well-arranged pores. (b) Image highlighting the primary layer (c) that is $\sim 20 \mu \mathrm{m}$ thick and the secondary layer (d) that is $\sim 8$ $\mu \mathrm{m}$ thick. (c) Spatial imaging of the primary layer depicting overlapping rod-shaped lathes. (d) Spatial imaging of the secondary layer revealing stacked rhomboidal tablets with pores. The tablets are up to $12.2 \mu \mathrm{m}$ long and $6.6 \mu \mathrm{m}$ wide.

550

Fig. 7 Field emission gun scanning electron microscope images of skeletal imaging of Discinisca tenuis shell after thermal analysis. (a) Spatial ultrastructural architecture showing a cast of the imprint pattern of a calcium phosphate mineral, the thickness of which is $21 \mu \mathrm{m}$. (b) Detail of the shell cross-sectional image showing a domain of rod-shaped crystals within a confined part of a calcium phosphate mineral. (c) External shell surface depicting the randomly oriented rod-shaped crystals. (d) Image showing spherical tablets that are $\sim 15.9 \mu \mathrm{m}$ long and $\sim 14.8 \mu \mathrm{m}$ wide. (e) Inset in (d) shows rod-shaped crystals in the tablets.

Fig. 8 Raman spectra of brachiopod shells (Lingula anatina and Discinisca tenuis) after thermal gravimetric analysis. (a) Complete range (400-1800 $\left.\mathrm{cm}^{-1}\right)$ showing a large Raman shift. (b) Expanded range $\left(400-1200 \mathrm{~cm}^{-1}\right)$. See Table 1 for band assignments. 
Table 1. Raman band and assignment for apatitic shell biominerals after thermal gravimetric

572 analysis.

\begin{tabular}{|c|c|c|}
\hline L. anatina & D. tenuis & Assignment \\
\hline $430(s)$ & $431(\mathrm{~s})$ & $v_{2}$ doubly degenerate bending modes of $\mathrm{PO}_{4}{ }^{3-}$ \\
\hline 445(m) & $449(\mathrm{~m})$ & $v_{2}$ doubly degenerate bending modes of $\mathrm{PO}_{4}^{3-}$ \\
\hline $450(\mathrm{sh})$ & $455(\mathrm{sh})$ & $v_{2}$ doubly degenerate bending modes of $\mathrm{PO}_{4}{ }^{3-}$ \\
\hline $581(\mathrm{~m})$ & $582(\mathrm{sh})$ & $v_{4}$ triply degenerate bending modes of $\mathrm{PO}_{4}{ }^{3-}$ \\
\hline $591(\mathrm{~s})$ & $591(\mathrm{~s})$ & $v_{4}$ triply degenerate bending modes of $\mathrm{PO}_{4}{ }^{3-}$ \\
\hline 607(m) & $607(\mathrm{~m})$ & $v_{4}$ triply degenerate bending modes of $\mathrm{PO}_{4}^{3-}$ \\
\hline $616(w)$ & $617(\mathrm{sh})$ & $v_{4}$ triply degenerate bending modes of $\mathrm{PO}_{4}{ }^{3-}$ \\
\hline \multirow[t]{2}{*}{$637(\mathrm{vw})$} & 631(vw) & $v_{\mathrm{L}}$ liberational mode of $\mathrm{OH}$ bond \\
\hline & $648(\mathrm{vw})$ & $v_{\mathrm{L}}$ liberational mode of $\mathrm{OH}$ bond \\
\hline $795(\mathrm{vw})$ & & $v_{4}$ in-plane deformation bending modes of $\mathrm{CO}_{3}{ }^{2-}$ \\
\hline \multirow[t]{2}{*}{$828(w)$} & & $v_{4}$ mode of $\mathrm{CO}_{3}{ }^{2-}$ and/or $\mathrm{PO}_{4}{ }^{3-}$ impurities \\
\hline & $870(\mathrm{vw})$ & $v_{2}$ bending mode of $\mathrm{CO}_{3}{ }^{2-}$ group \\
\hline $950(\mathrm{sh})$ & & $v_{1}$ nondegenerate symmetric stretching mode of the $\mathrm{PO}_{4}{ }^{3-}$ \\
\hline $965(\mathrm{vs})$ & $965(\mathrm{vs})$ & $v_{1}$ nondegenerate symmetric stretching mode of the $\mathrm{PO}_{4}{ }^{3-}$ \\
\hline $996(w)$ & $997(w)$ & $v_{1}$ asymmetric stretching of the $\mathrm{HPO}_{4}{ }^{2-}$ \\
\hline $1010(w)$ & $1010(w)$ & $v_{1}$ asymmetric stretching mode of the $\mathrm{HPO}_{4}{ }^{2-}$ \\
\hline $1022(\mathrm{sh})$ & $1024(\mathrm{sh})$ & $\begin{array}{l}v_{3} \text { asymmetric stretching of } \mathrm{PO}_{4}{ }^{3-} \text { and/or } \mathrm{CO}_{3}{ }^{2-} \text { and crystal } \\
\text { imperfections in nonstoichiometric apatite }\end{array}$ \\
\hline 1034(w) & 1034(sh) & $v_{3}$ triply degenerated asymmetric stretching mode of the $\mathrm{PO}_{4}{ }^{3-}$ \\
\hline $1042(\mathrm{~m})$ & $1042(w)$ & $v_{3}$ triply degenerated asymmetric stretching mode of the $\mathrm{PO}_{4}{ }^{3-}$ \\
\hline $1053(\mathrm{~s})$ & $1053(\mathrm{~s})$ & $v_{3}$ triply degenerated asymmetric stretching mode of the $\mathrm{PO}_{4}{ }^{3-}$ \\
\hline 1059 (sh) & $1063(\mathrm{sh})$ & $v_{3}$ triply degenerated asymmetric stretching mode of the $\mathrm{PO}_{4}{ }^{3-}$ \\
\hline \multirow[t]{3}{*}{$1080(\mathrm{~m})$} & $1080(\mathrm{~m})$ & $\begin{array}{l}v_{3} \text { triply degenerated asymmetric stretching mode of the } \mathrm{PO}_{4}{ }^{3-} \\
\text { and/or } v_{1} \text { symmetric stretching mode of } \mathrm{CO}_{3}{ }^{2-}\end{array}$ \\
\hline & $1131(\mathrm{vw})$ & $\begin{array}{l}v_{3} \text { asymmetric stretching of the } \mathrm{HPO}_{4}{ }^{2-} \text { and/or } v_{1} \text { symmetric } \\
\text { stretching mode of } \mathrm{CO}_{3}{ }^{2-}\end{array}$ \\
\hline & $1152(\mathrm{vw})$ & $v_{1}$ symmetric stretching mode of $\mathrm{CO}_{3}^{2-}$ \\
\hline
\end{tabular}




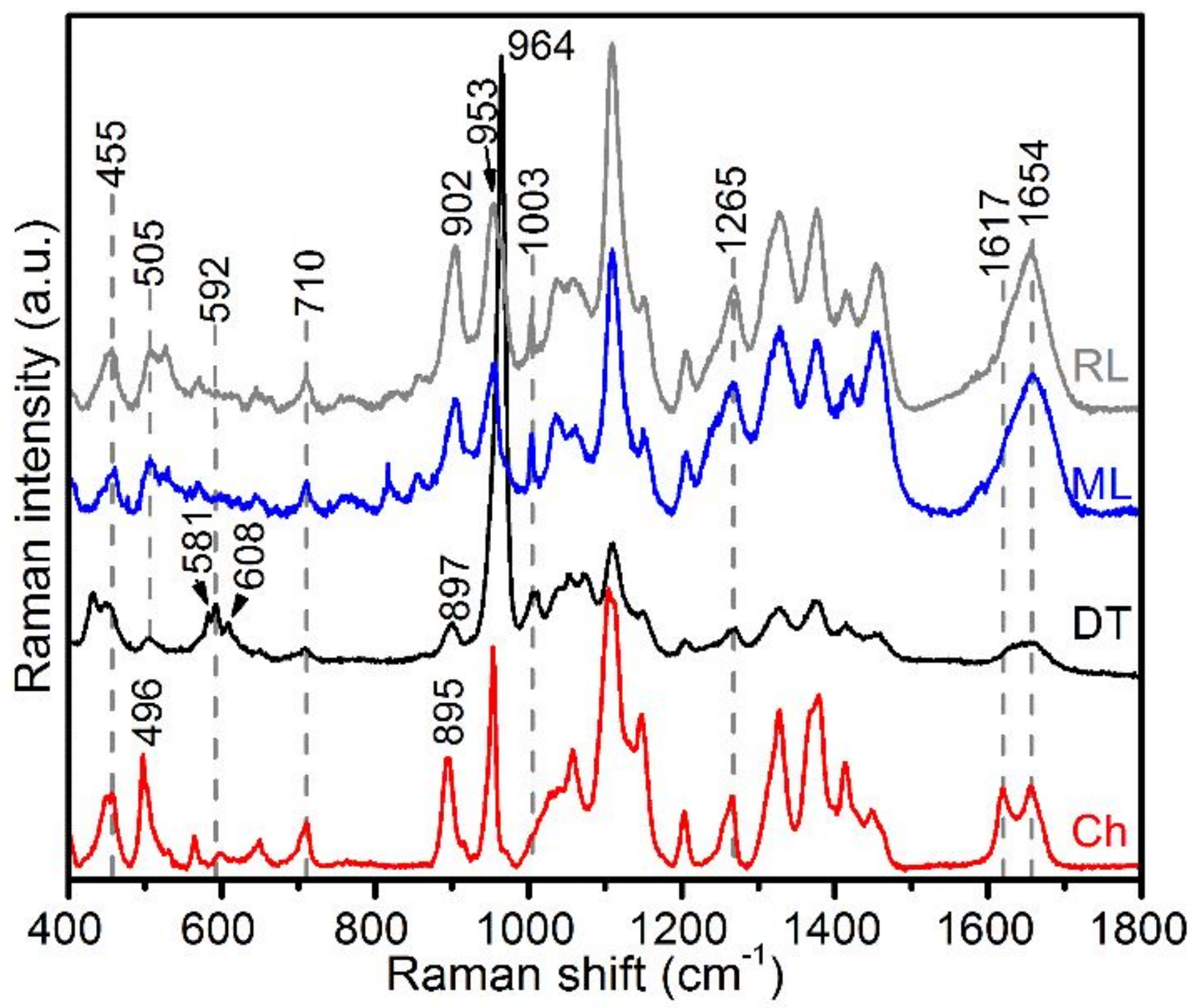

Figure 1

Raman spectra (acquired using a 633-nm laser) of chitin fibre from brachiopod shells: Lingula anatina (modern/living (ML) and Recent (RL), Recent Discinisca tenuis (DT), and pure a-chitin (Ch) as a reference. The baselines of the spectra are corrected. The amide I single band at $\sim 1654 \mathrm{~cm}-1$ is due to chitin fibre, and is characteristic of $\beta$-chitin. This is dissimilar from $\alpha$-chitin that possesses double bands at 1617 and $1654 \mathrm{~cm}-1$. The amide I band of Discinisca is broad compared to the Lingula shells. See SI Fig. 1 for band deconvolution. Discinisca also contains prominent phosphate (vPO43-) vibrational modes at 964 $\mathrm{cm}-1,608 \mathrm{~cm}-1$ and $581 \mathrm{~cm}-1$. See SI Table 1 for band assignments. 

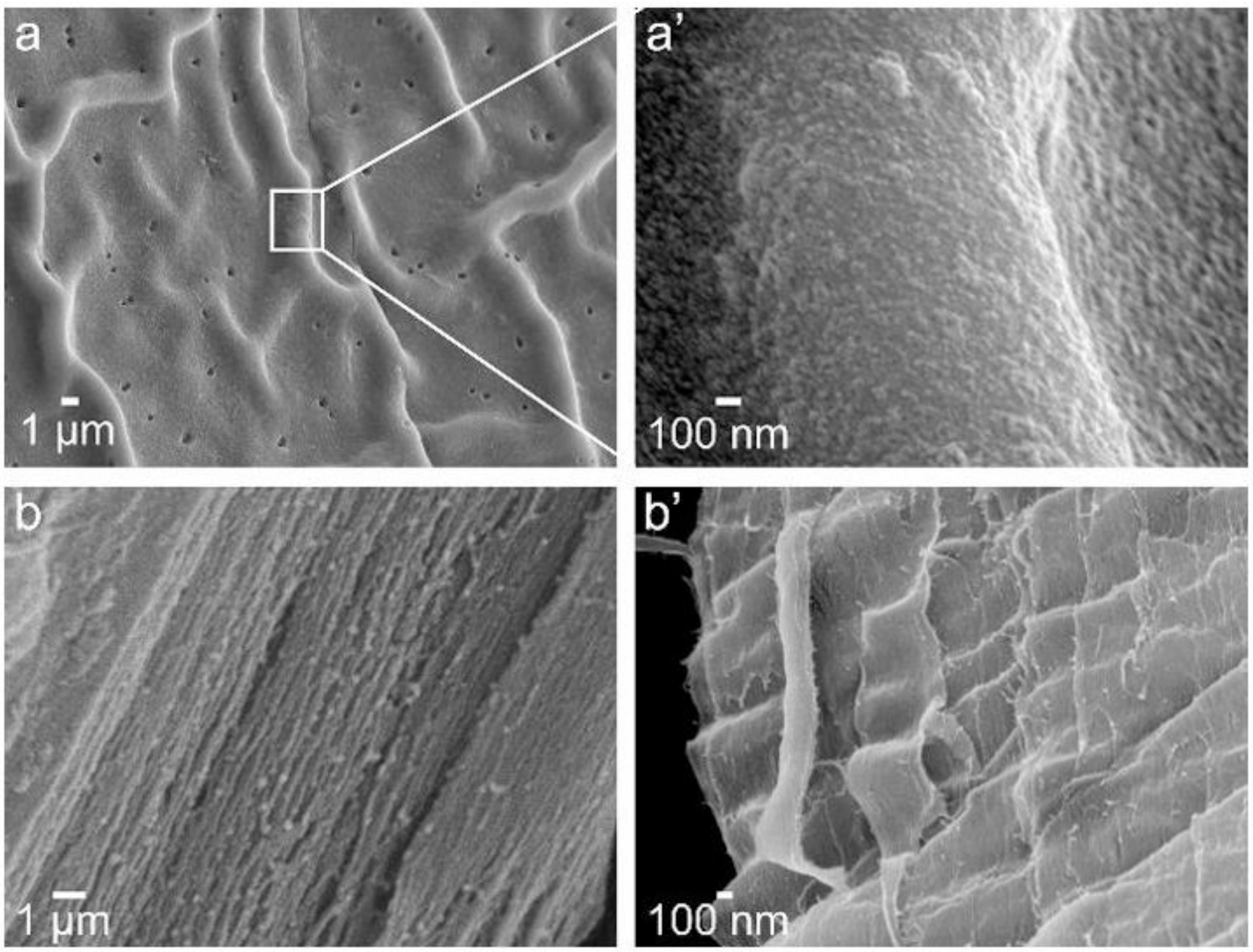

\section{Figure 1}

Field emission gun scanning electron microscope images of $\beta$-chitin organic fibre from brachiopod shells. (a) Representative fibre surface of Lingula anatina showing pores and radiating units of the ridges. (a') The ridge is expanded to show nanoparticle granules. (b, $\left.b^{\prime}\right)$ External surface of Discinisca tenuis organic fibre showing a lamellar ultrastructure. Note: The designations employed and the presentation of the material on this map do not imply the expression of any opinion whatsoever on the part of Research Square concerning the legal status of any country, territory, city or area or of its authorities, or concerning the delimitation of its frontiers or boundaries. This map has been provided by the authors. 

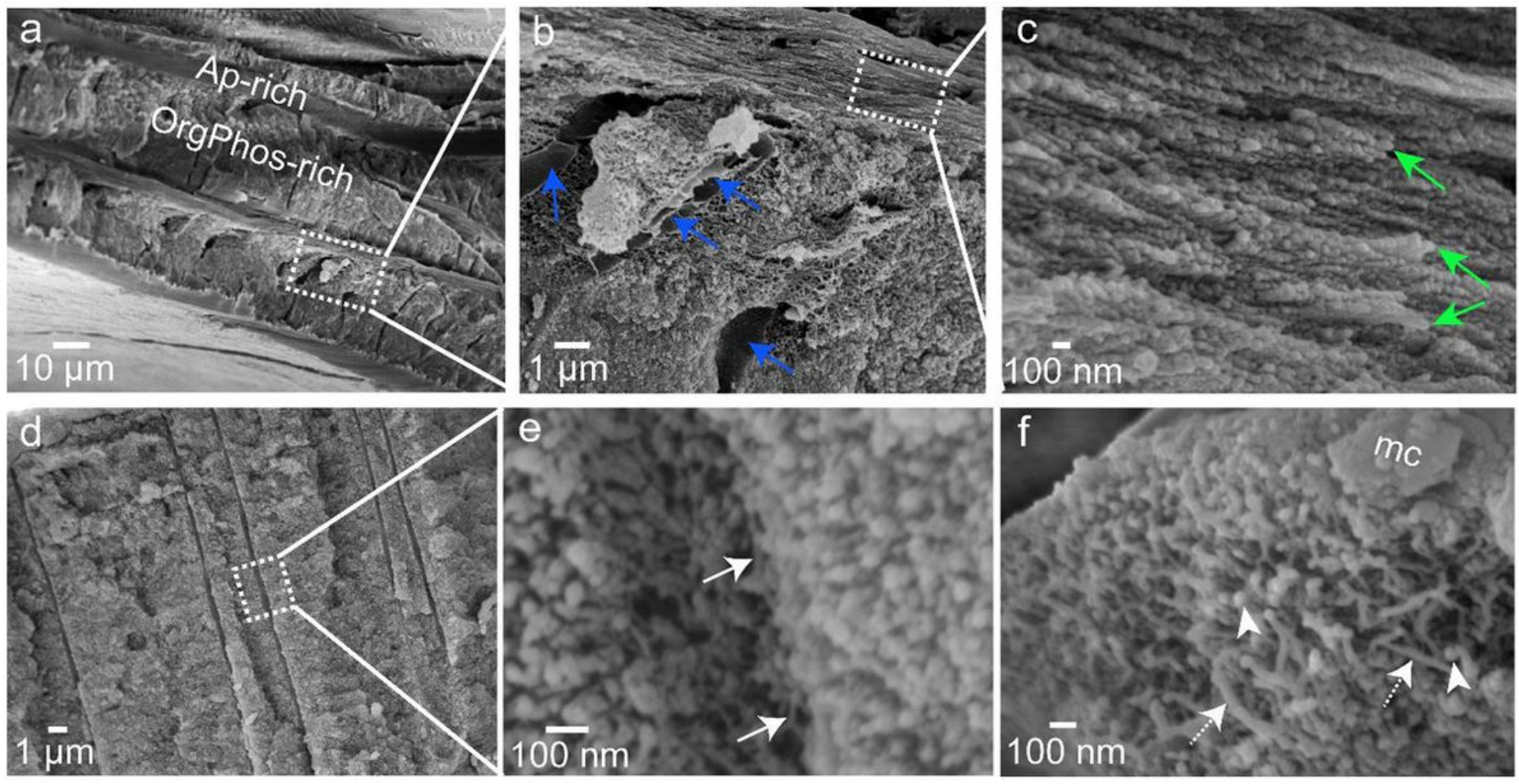

\section{Figure 1}

Field emission gun scanning electron microscope images of sodium hydroxide-treated Lingula anatina (a-c) and Discinisca tenuis (d-f) shells. (a) Fracture surface of Lingula shell showing apatite-rich (Ap-rich) and organophosphatic-rich (OrgPhos-rich) laminae. (b) Organic sheets/fibres (blue arrows) in the organophosphatic-rich layer are highlighted. These sheets are arranged roughly perpendicular to the apatite-rich layer, but do not permeate into it. (c) Biomineralized ruptured fibrils (green arrows) on the fracture surface of an apatite-rich layer. The nanoparticle granule sizes are in the $\sim 50-70 \mathrm{~nm}$ range. (d) Ultrastructure of Discinisca shell depicting canals. (e) Nanoparticle granules in the $\sim 50-100 \mathrm{~nm}$ range, and organic fibrils (white arrows). (f) Fracture section showing nano-rods (dashed arrows), mosaics (mc), and spherical micro-apatite in the 50-60 nm range (arrowheads). Note: The designations employed and the presentation of the material on this map do not imply the expression of any opinion whatsoever on the part of Research Square concerning the legal status of any country, territory, city or area or of its authorities, or concerning the delimitation of its frontiers or boundaries. This map has been provided by the authors. 

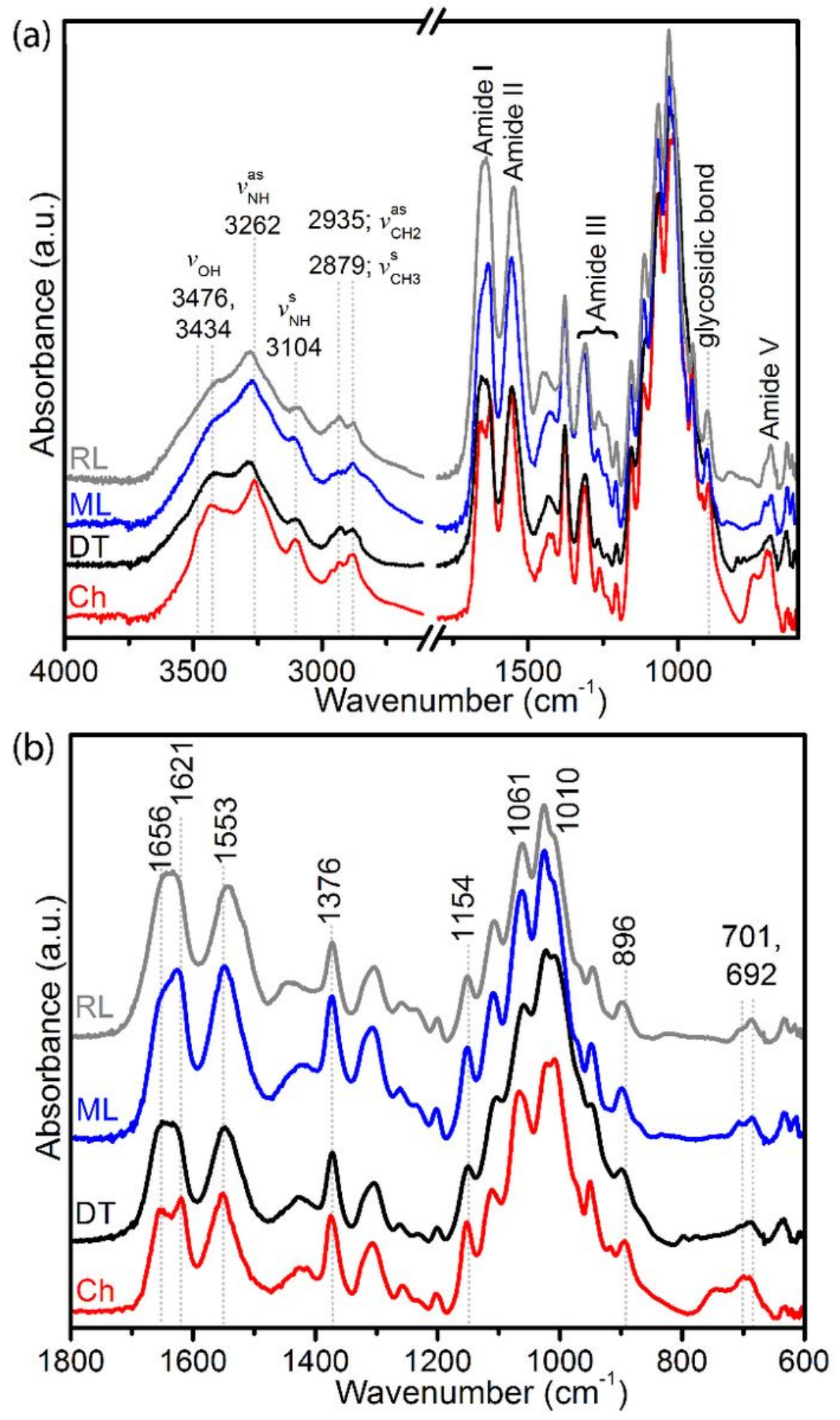

Figure 1

FTIR spectra of chitin fibre from brachiopod shells: Lingula anatina, Recent (RL) and modern/living (ML), Recent Discinisca tenuis (DT), and pure a-chitin (Ch) as a reference. (a) Shows a larger wavenumber range (4000-600 cm-1) than the expanded range (1800-600 cm-1) in (b). 

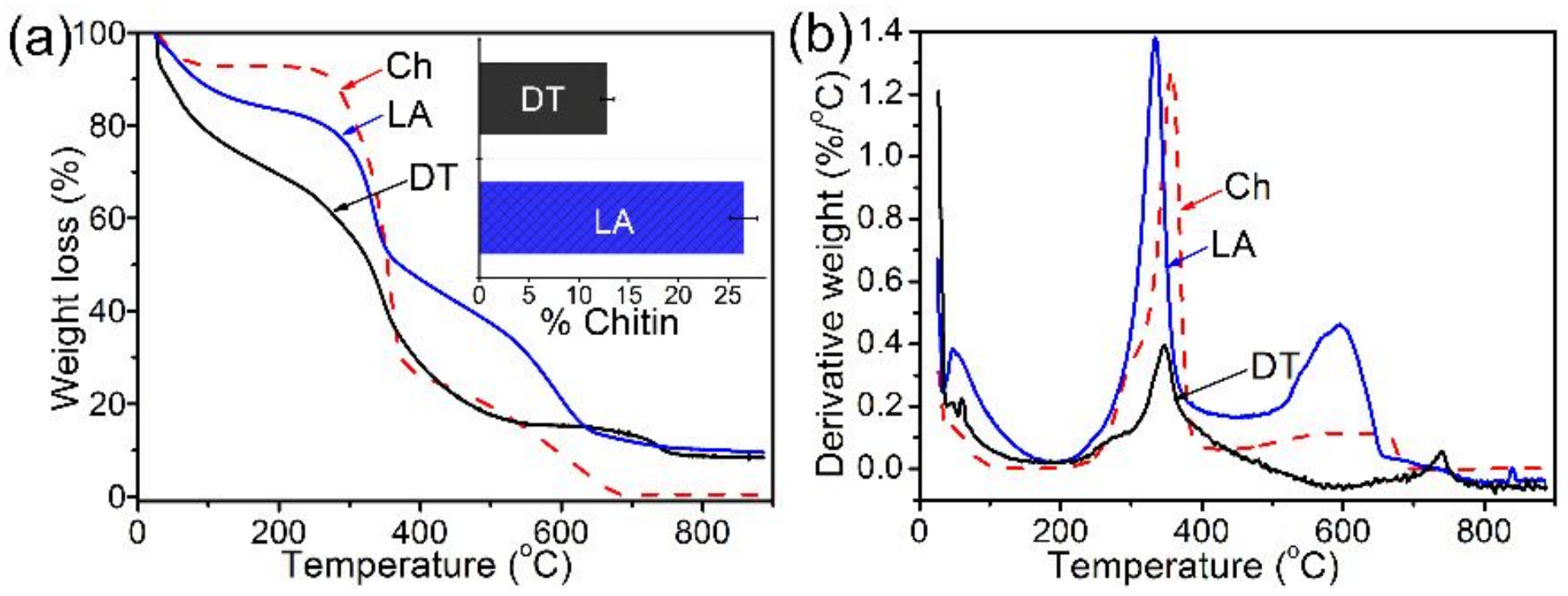

Figure 1

(a) Thermal gravimetric analysis data and (b) differential thermal gravimetric analysis data of shell biominerals (LA: Lingula anatina, DT: Discinisca tenuis) and pure a-chitin (Ch). The bar chart in (a) represents the calculated total polysaccharide chitin contents in the $200-650^{\circ} \mathrm{C}$ range. L. anatina and D. tenuis comprise $26.6 \mathrm{wt} . \%$ and $12.9 \mathrm{wt} . \%$ total polysaccharide matrix, respectively. 

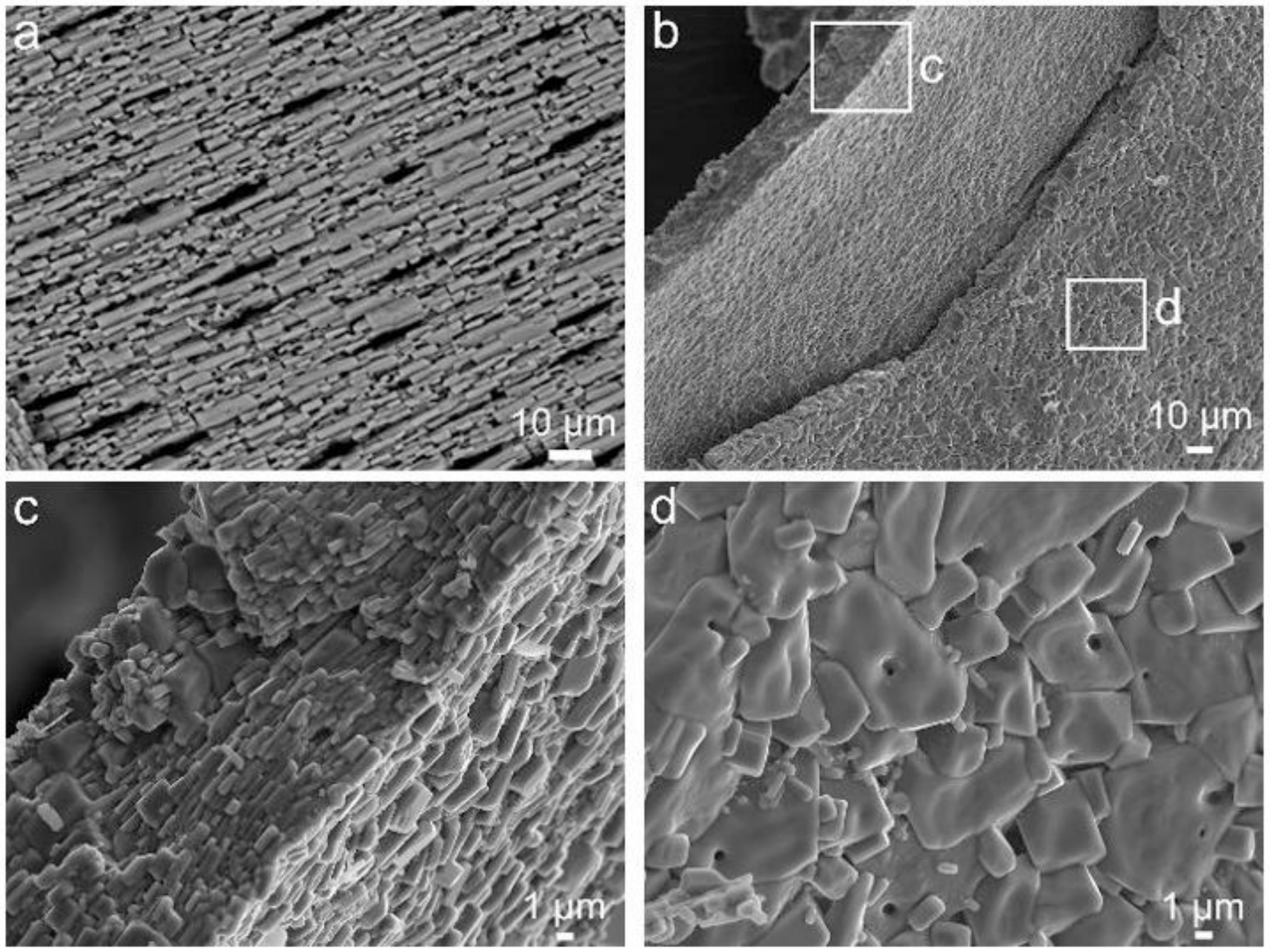

\section{Figure 1}

Lingula anatina shell architecture after thermal analysis by back-scattered electron imaging (a) and field emission gun scanning electron microscopy (b-d). (a) Representative external shell surface showing nano-sized crystal rods and well-arranged pores. (b) Image highlighting the primary layer (c) that is 20 $\mu \mathrm{m}$ thick and the secondary layer (d) that is $\sim 8 \mu \mathrm{m}$ thick. (c) Spatial imaging of the primary layer depicting overlapping rod-shaped lathes. (d) Spatial imaging of the secondary layer revealing stacked rhomboidal tablets with pores. The tablets are up to $12.2 \mu \mathrm{m}$ long and $6.6 \mu \mathrm{m}$ wide. Note: The designations employed and the presentation of the material on this map do not imply the expression of any opinion whatsoever on the part of Research Square concerning the legal status of any country, territory, city or area or of its authorities, or concerning the delimitation of its frontiers or boundaries. This map has been provided by the authors. 

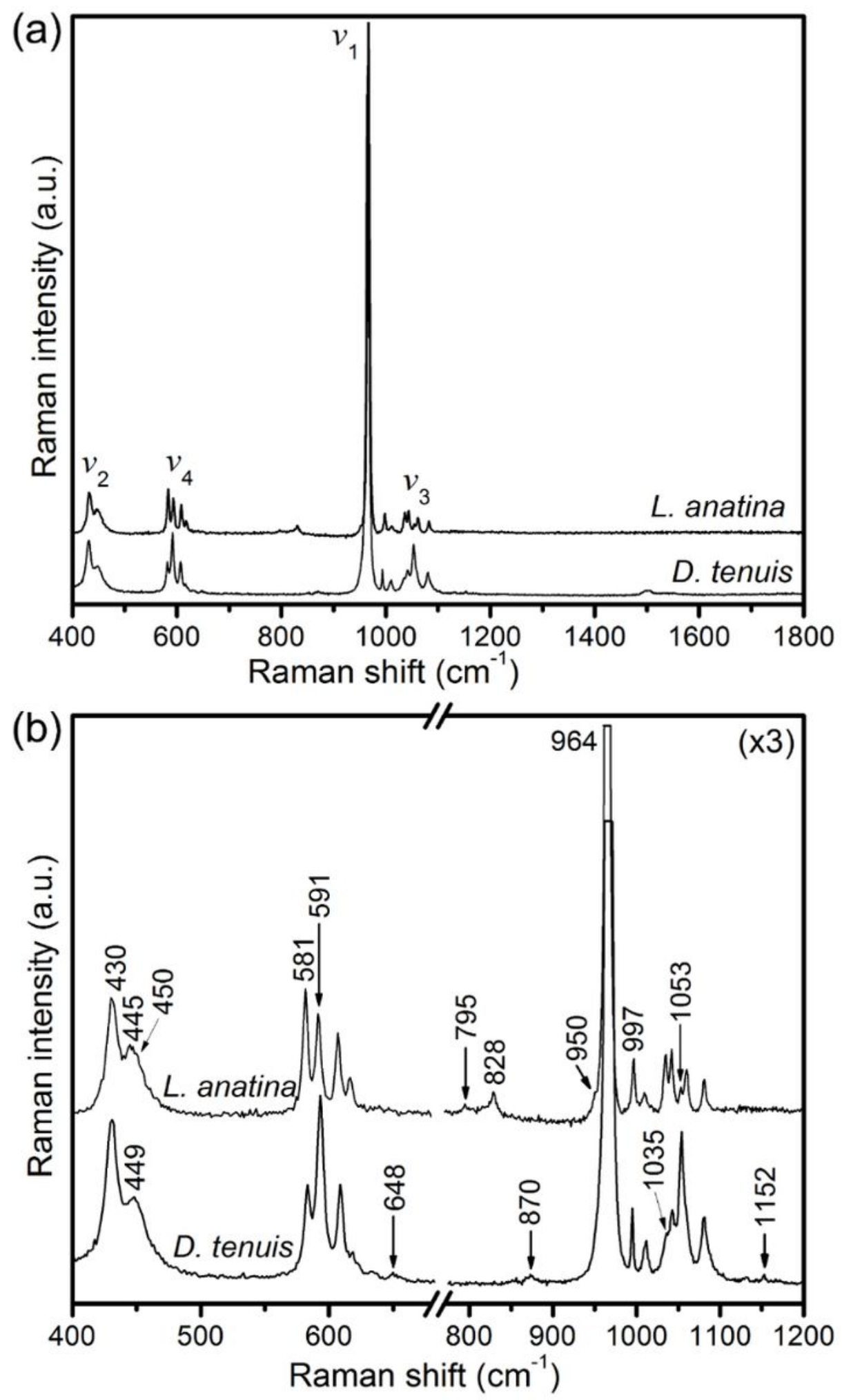

Figure 1

Raman spectra of brachiopod shells (Lingula anatina and Discinisca tenuis) after thermal gravimetric analysis. (a) Complete range (400-1800 cm-1) showing a large Raman shift. (b) Expanded range (400$1200 \mathrm{~cm}-1)$. See Table 1 for band assignments. 

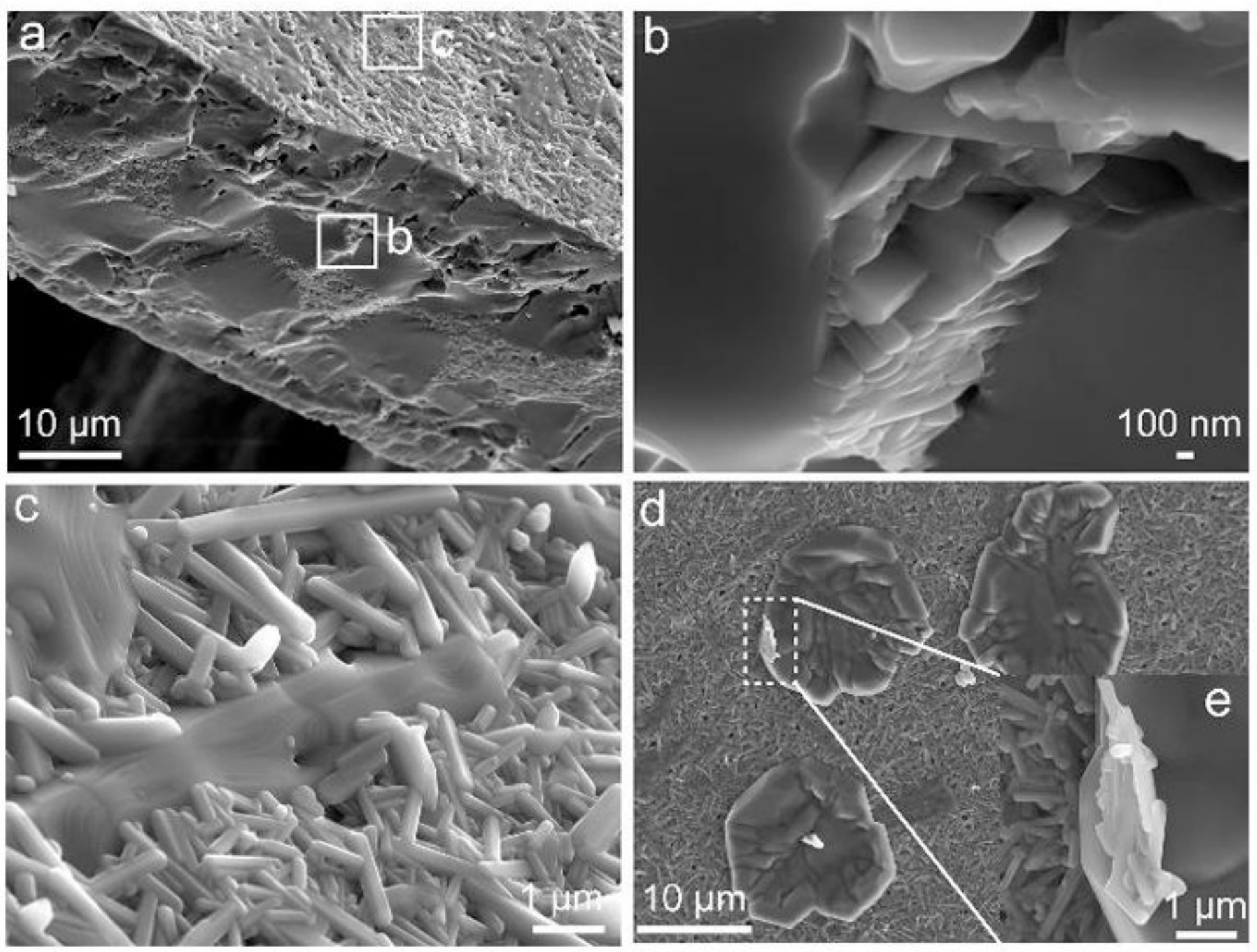

\section{Figure 1}

Field emission gun scanning electron microscope images of skeletal imaging of Discinisca tenuis shell after thermal analysis. (a) Spatial ultrastructural architecture showing a cast of the imprint pattern of a calcium phosphate mineral, the thickness of which is $21 \mu \mathrm{m}$. (b) Detail of the shell cross-sectional image showing a domain of rod-shaped crystals within a confined part of a calcium phosphate mineral. (c) External shell surface depicting the randomly oriented rod-shaped crystals. (d) Image showing spherical tablets that are $\sim 15.9 \mu \mathrm{m}$ long and $\sim 14.8 \mu \mathrm{m}$ wide. (e) Inset in (d) shows rod-shaped crystals in the tablets. Note: The designations employed and the presentation of the material on this map do not imply the expression of any opinion whatsoever on the part of Research Square concerning the legal status of any country, territory, city or area or of its authorities, or concerning the delimitation of its frontiers or boundaries. This map has been provided by the authors.

\section{Supplementary Files}

This is a list of supplementary files associated with this preprint. Click to download. 
- AgbajeetalChitinESImain.pdf 